\title{
TALFĪQ DALAM BERMADZHAB (KAJIAN PEMIKIRAN IBRAHIM HOSEN)
}

\author{
Mohamad Rana \\ Fakultas Syariah dan Ekonomi Islam \\ Institut Agama Islam Negeri Syekh Nurjati Cirebon \\ Jl. Perjuangan By Pass Sunyaragi Cirebon \\ Email: mohamadrana85@yahoo.com
}

\begin{abstract}
Abstrak
Talfĭq dalam khazanah hukum Islam mulai populer pada periode ulama muta'akhirin. Kemunculannya dilatar belakangi ketika mewabahnya sikap taqlid dalam madzhab yang melanda oleh umat Islam. Istilah talfì dalam madzhab menjadi perhatian serius Ibrahim Hosen, seorang pakar Ushul Fiqh dan Fiqh dari Indonesia. Dalam Penelitian ini, penulis berusaha menelusuri pemikiran Ibrahim Hosen dalam masalah talfíq, baik berkaitan dengan biografinya, maupun landasan pemikirannya. Dari hasil penelitian penulis sendiri, Ibrahim Hosen lebih cenderung membolehkan talfiq, karena sejalan dengan prinsip agama Islam, yang memberikan kemudahan bagi umatnya. Akan tetapi pengamalan talfĭq itu sendiri tidaklah bersifat mutlak, talfīq dapat dilakukan apabila situasi dan kondisi yang tidak memungkinkan (dharurat).
\end{abstract}

Kata Kunci: talfīq, Madzhab, dan Ibrahim Hosen

\begin{abstract}
Talfiq in the treasury of Islamic law began to popular in the period ulama muta'akhirin. The emergence of the background when the outbreak of taqlid attitude in schools that hit by Muslims. The term talfiq in the madhhab became a serious concern Ibrahim Hosen, an expert of Ushul Fiqh and Fiqh from Indonesia. In this study, the author tries to trace the thought of Ibrahim Hosen in the matter talfiq, both related to biography, as well as the basis of his thinking. From the results of the authors own research, Ibrahim Hosen more likely to allow talfiq, because in line with the principle of Islam, which provides convenience for its people. However, the exercise of talfiq itself is not absolute, talfiq can be done if situations and conditions are not possible (dharurat).
\end{abstract}

Keywords: talfiq, Madzhab, and Ibrahim Hosen 


\section{PENDAHULUAN}

Islam merupakan agama sempurna yang diturunkan Allah, Swt. melalui RasulNya yang mulia, Nabi Muhammad, Saw. Dikatakan sempurna, karena syari'at Islam merupakan pelengkap dari syari'at yang Allah turunkan kepada para Nabi sebelum Nabi Muhammad, Saw.

Syari'at Islam memiliki prinsip yang tidak dimiliki oleh agama-agama lain, salah satunya adalah kemudahan. Prinsip tersebut menjadikan Syari'at Islam senantiasa sesuai dengan kondisi dan situasi manusia yang terus berjalan.

Dalam upaya memahami Syari'at Islam itu sendiri, tidak semua umat Islam mampu untuk memahami dan juga menggali norma-norma yang terkandung didalamnya (istinbath al-hukm), dibutuhkan sarana perangkat keilmuan tertentu sebagaimana yang telah ditentukan oleh para ulama dalam upaya tersebut, sehingga dalam kajian hukum Islam (baca: fiqh), umat Islam yang tidak mampu memahami kandungan yang tertuang dalam nash-nash suci (an-nush üsh al-muqaddasah), yakni al-Qur'an dan Hadits maupun tidak memiliki kualifikasi perangkat keilmuan disebut sebagai orang awam. Sedangkan bagi seseorang yang mampu memenuhi kualifikasi keilmuan yang telah ditentukan, ia dapat melakukan penggalian hukum yang terkandung dalam kedua sumber tersebut, atau dalam kajian hukum Islam, ia disebut sebagai mujtahid.

Dalam realitasnya, upaya ijtihad para mujtahid dalam menggali ataupun menjawab segala problema umat, tidak semua memiliki kesimpulan hukum yang sama dalam satu permasalahan.

Perbedaan pendapat dikalangan ulama dalam kajian hukum Islam sendiri merupakan sebuah keniscayaan. Hal ini karena masing-masing mujtahid memiliki metodologi yang berbeda dalam melakukan ijtihadnya. Perbedaan tersebut pada akhirnya melahirkan aliran-aliran hukum Islam, atau dikenal dengan istilah madzhab. Setiap madzhab memiliki corak hukumnya tersendiri berdasarkan hasil ijtihadnya yang berbeda dengan madzhab-madzhab lain.

Kemunculan madzhab fiqh pada gilirannya menimbulkan permasalahan baru, khususnya pada periode ulama muta'akhirin, yakni tentang wajib tidaknya umat Islam menganut madzhab tertentu dan boleh tidaknya berpindah madzhab dari yang satu ke madzhab yang lain, baik sebagian ataupun secara keseluruhan dari fatwa ataupun pendapat imam madzhab, serta boleh tidaknya mengambil pendapat yang ringan dari setiap madzhab untuk diamalkan atau dikenal dengan istilah talfiq .

Kemunculan istilah talfīq dalam bermadzhab menimbulkan perdebatan dikalangan ulama, terkait boleh tidaknya pengamalan talfiq itu sendiri. Perdebatan seputar masalah talfiq dikalangan ulama tersebut mendapat perhatian dan pengkajian serius oleh para pakar Hukum Islam, khususnya di Indonesia yang salah satunya adalah Prof. KH. Ibrahim Hosen, MLM., seorang pakar fiqh dan Ushul Fiqh.

\section{PEMBAHASAN}

\section{Konsep Dasar Bermadzhab Definisi Madzhab}

Kata "madzhab" adalah merupakan shighat (bentuk) isim makan (kata yang menunjukkan tempat) yang terambil dari lafad dzahaba (ذهب ) yang memiliki arti pergi. Secara etimologi kata "madzhab" memiliki arti "pendirian" (al-mu'taqad), "jalan" atau "sistem" (al-tharīqah), 
"sumber" atau "pendapat yang kuat" (alashl). ${ }^{l}$

Sedangkan pengertian madzhab secara terminologi, terdapat berbagai ragam definisi yang diberikan ulama terkait pengertiannya. Di bawah ini penulis uraikan ragam definisi madzhab pandangan ulama.

a. Imam Az-Zarqani ${ }^{2}$

Pendapat yang diambil oleh seorang imam dan para imam dalam masalah yang terkait dengan hukum-hukum ijtihadiyah.

b. M. Said Ramadlan al-Buthi ${ }^{3}$

Jalan pikiran, paham, ataupun pendapat yang ditempuh oleh seorang imam mujtahid di dalam menetapkan suatu hukum Islam dari al-Qur`an dan al-Hadits.

c. Ibrahim Hosen ${ }^{4}$

Hasil ijtihad seorang imam (mujtahid muthlaq mustaqil) tentang hukum suatu masalah, atau tentang kaidahkaidah istinbath.

d. Huzaemah Tahido Yanggo ${ }^{5}$ Madzhab adalah pokok pikiran atau dasar yang digunakan oleh Imam Mujtahid dalam memecahkan masalah, atau meng-istinbathkan hukum Islam.

${ }^{1}$ M.Said Ramadhan al-Buthi, Alamadzhābiah Akhthuru Bid'atin Tuhaddidu al-Syari'ah alIslamiyah, diterjemahkan oleh Gazira Abdi Ummah, Jakarta: Pustaka Al- Kautsar, 2001, hal.15. juga lihat, Ibrahim Hosen, Memecahkan Permasalahan Hukum Baru, dalam Jalaluddin Rahmat (ed.) Ijtihad Dalam Sorotan, Bandung: Mizan, 1992, hal. 34

2 Az-Zarqani, Syarh az-Zarqani, Beirut: alMaktabah al-'Ishriyyah, hal. 13318

${ }^{3}$ M.Said Ramadhan al-Buthi, Alamadzhābiah Akhthuru ..., hal.15

4 Ibrahim Hosen, Memecahkan Permasalahan...hal. 34

${ }^{5}$ Huzaemah Tahido Yanggo, 2011, Pengantar Perbandingan Madzhab, Jakarta: Logos Wacana Ilmu, 1997, hal. 72
Dengan demikian, dari beberapa definisi madzhab di atas, dapat disimpulkan bahwa istilah madzhab dapat dipahami mengandung dua arti: pertama, cara berfikir atau metode berijtihad yang diterapkan oleh mujtahid untuk menentukan hukum suatu kasus berdasarkan al-Qur'an dan hadits. Kedua, fatwa atau pendapat mujtahid tentang hukum suatu kasus atau peristiwa yang diambil dari al-Qur'an dan Hadits. ${ }^{6}$

\section{Hukum Bermadzhab}

Istilah "bermadzhab" dalam Kamus Besar Bahasa Indonesia diartikan sebagai "mempunyai madzhab; mengikuti madzhab" . Dengan demikian, secara tekstual bermadzhab dapat diartikan orang yang mengikuti salah satu madzhab fiqh, baik secara metodologi ijtihad yang dirumuskan oleh Imam madzhab, maupun mengikuti fatwa atau hasil ijtihad mujtahid.

\begin{tabular}{|c|c|}
\hline Berkaitan & dengan \\
\hline $\begin{array}{l}\text { bermadzhab sendiri, } \\
\text { mengklasifikasikannya } \\
\text { tingkatan: }\end{array}$ & $\begin{array}{l}\text { Muchit } \\
\text { kedalam }\end{array}$ \\
\hline
\end{tabular}

1) Bermadzhab dalam tingkat mengikuti produk (hasil) ijtihad orang lain, sama sekali tidak mampu berijtihad sendiri, bahkan tidak tahu dalil yang dipergunakan;

2) Bermadzhab dalam tingkat mampu "berijtihad sendiri" secara sangat terbatas, seperti seorang santri yang sudah mampu menguasai problematika fardhunya wudhu, mulai dari dalil-

\footnotetext{
6 Djohan Efendi, Pembaharuan Tanpa Membongkar Tradisi: Wacana Keagamaan di Kalangan generasi Muda NU Masa Kepemimpinan Gus Dur, Jakarta: Kompas, 2010, hal. 146

7 Departemen Pendidikan dan Kebudayaan, Kamus Besar Bahasa Indonesia, Jakarta: Balai Pustaka, 1989, hal. 726

8 Djohan Efendi, Pembaharuan Tanpa Membongkar...hal. 146-147
} 
dalilnya, pengelolaan dalil, serta penyimpulannya;

3) Bermadzhab dalam tingkat sudah mampu berijtihad sendiri dengan mempergunakan metode dan pola pemahaman yang diciptakan oleh tokoh lain.

Dari pengklasifikasian di atas dapat dipahami bahwa tidak semua orang memiliki pemahaman yang mapan terkait hukum Islam, terdapat kelompok umat yang secara pemahaman dibawah kemampuan para ulama mujtahid atau yang biasa disebut sebagai orang awam, sehingga dalam beramal tidak memiliki kemampuan secara mandiri untuk menggali hukum yang tertuang dalam al-Qur'an maupun Hadits Nabi, Saw. Dan ada pula kelompok umat yang mampu secara mandiri untuk menggali hukum, baik dari al-Qur'an maupun Hadits Nabi, Saw. Realitas tersebut, menurut Ibrahim Hosen, bahwa mengenai suatu masalah yang hukumnya belum ditegaskan oleh nash, maka bagi yang memiliki kemampuan untuk berijtihad, ia berkewajiban untuk berijtihad dan mengamalkan hasil ijtihadnya. Sedangkan bagi yang tidak mampu untuk melakukan ijtihad (orang awam dan ulama yang tidak mampu melakukan ijtihad), maka ia berkewajiban mengamalkan hasil ijtihad salah seorang imam mujtahid (taqlid). Hal ini sejalan dengan firman Allah, Swt.:

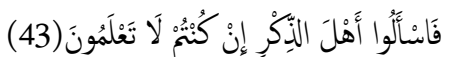

"Bertanyalah kepada ahl dizkri (ulama) apabila kamu tidak mengerti." (QS. An-Nahl: 43)

Terkait kewajiban orang awam untuk mengamalkan hasil ijtihad salah satu Imam Madzhab sebagaimana yang dikatakan Ibrahim Hosen di atas, memunculkan suatu pertanyaan, yaitu apakah hal tersebut membuat orang awam berkewajiban menganut kepada salah satu madzhab fiqh yang ada?. Dalam hal ini, menurut Abi Yahya Zakariya al-Anshori, terdapat dua pendapat:

Pendapat pertama, wajib menganut madzhab tertentu yang diyakininya lebih unggul atau setara, meskipun pada kenyataannya madzhab tersebut marjuh. Pendapat kedua, tidak wajib menganut madzhab tertentu. Mereka boleh mengambil pendapat dari madzhab manapun yang disukai dalam sebuah permasalahan yang dihadapi. $^{9}$

Senada dengan Abi Yahya Zakariya al-Anshori di atas, ulama Ushuliyyin sendiri berbeda pendapat perihal wajib tidaknya bekomitmen terhadap salah satu madzhab, dalam hal ini ada tiga pendapat:

(1) Sebagian ulama mewajibkan umat Islam untuk mengikuti madzhab tertentu, karena adanya keyakinan bahwa madzhab tertentu adalah benar, maka wajib mengikuti kebenaran yang diyakini;

(2) Mayoritas ulama ushuliyyûn tidak mewajibkan untuk mengikuti atau taqlid madzhab tertentu dalam menentukan hukum suatu permasalahan, namun diperbolehkan mengikuti ulama siapapun yang mereka kehendaki. Apabila seseorang mengkikuti madzhab imam tertentu, seperti Abu Hanifah, Syafi'i dan lainnya, maka tidak wajib untuk terus mengikuti pendapat mereka, tapi diperbolehkan untuk berpindah madzhab dalam permasalahan tertentu. Alasan pendapat kedua ini, karena tidak ada kewajiban selain yang diwajibkan Allah dan Rasul-Nya, sementara Allah dan Rasul-Nya tidak mewajibkan kepada umat Islam untuk bermadzhab.

${ }^{9}$ Darul Azka, et.al, Lubb al-Ushul: Kajian Intisari Dua Ushul, Lirboyo: Santri Salaf Press, 2017, hal. 231 
Allah, Swt. hanya memerintahkan umat Islam untuk mengikuti ulama dan menanyakan kepada mereka mengenai hal-hal yang tidak diketahui. Pendapat yang menyatakan kewajiban mengikuti madzhab tertentu malah akan menyulitkan seseorang padahal madzhab adalah keutamaan dan rahmat untuk umat. Pendapat kedua ini merupakan pendapat yang rajih di kalangan ulama.

(3) Al-Amidi dan Kamal ibn al-Hammam, apabila seseorang dalam memutuskan suatu permasalah atau mengamalkan sesuatu mengikuti madzhab tertentu, maka tidak diperbolehkan baginya untuk berpindah madzhab dalam permasalahan tersebut. Ulama lain yang berpendapat demikian adalah alManshur Billah, Syaikh al-Hasan ibn Muhammad, dan Syaikh Ahmad ibn Muhammad. $^{10}$

Namun, apakah seorang muqallid (orang yang taqlid) disaat ia memilih seorang mujtahid atau madzhab, ia diharuskan konsisten dalam mengambil semua pendapat mujtahid atau madzhab tersebut dalam semua permasalahan?. Terkait dengan persoalan tersebut, ada dua pendapat berkenaan dengan hal itu: ${ }^{11}$

Pertama, wajib konsisten dalam berpegangan pada suatu madzhab dalam semua persoalan. Pendapat ini didukung oleh sekelompok ulama dan ditarjih oleh Ilkiya. Pendapat ini dilandasi dengan argumentasi bahwa ketika seorang muqallid sudah menyatakan kesanggupan pada madzhab tertentu, maka secara tidak

\footnotetext{
hal. 243 .

11 Muhammad bin Ali bin Muhammad alSyaukani, Irsyād al-Fuhūl ilā Tahqūq al-Haqq min 'Ilm al-Ushūl, Beirut: Dar al-Fikr, Tt, hal. 272. Lihat juga, Wahbah al-Zuhaily, Ushūl al-Fiqh al-Islāmi, Juz II, Beirut: Dar al-Fikr, 1989, hal. 1178.
}

${ }^{10}$ Ibnu Wazir, al-Raud al-Basim, II, Ebook, langsung telah meyakini kebenaran madzhab tersebut. Dengan demikian, wajib baginya untuk merealisasikan sesuatu yang dianggapnya benar.

Kedua, tidak wajib konsisten pada madzhab tertentu. Sehingga pada saat muqallid telah menyatakan kesanggupan pada madzhab tertentu, ia tidak wajib untuk meneruskannya. Ia boleh berpindah dari madzhab yang diikuti ke madzhab lain. Pendapat ini didukung oleh sekelompok ulama dan ditarjih oleh Ibn Burhan dan alNawawi. Argumentasi yang melandasi pendapat kedua ini adalah:

(1) Tidak ada kewajiban kecuali apa yang telah dibebankan Allah, Swt., dan Rasul-Nya. Dalam konteks ini Allah, Swt. hanya menyerukan untuk mengikuti ulama, tanpa menentukannya secara personal, hal ini sebagaimana tertuang dalam firman Allah, Swt. QS. An-Nahl: 43 di atas.

(2) Sejarah menunjukkan bahwa para peminta fatwa diera sahabat tidak selalu konsisten bertanya kepada sahabat tertentu, mereka pada umumnya sudah terbiasa meminta fatwa kepada siapa saja yang bersedia. Realitas ini terjadi tanpa ada seorang sahabat pun yang mengingkarinya. dengan demikian, terbentuklah ijma' bahwa tidak wajib bertaqlid pada madzhab tertentu dalam semua persoalan.

(3) Keharusan konsisten dalam bermadzhab akan berimbas mempersempit umat. Padahal perbedaan ulama adalah sebuah nikmat dan rahmat bagi umat. Sebagaimana halnya sabda Nabi, Saw. "Perbedaan umatku adalah rahmat." (HR. Baihaqi)

\section{Hukum Talfiq Antar Madzhab Fiqh Konsep Dasar Talfĩq}


Diskursus talfiq muncul dan menjadi perdebatan dikalangan ulama fiqh seiring dengan semakin meluasnya pola pikir taqlid umat Islam. Istilah talfiq sendiri dimunculkan oleh ulama' muta'akhirin, setelah abad ke $10 \mathrm{H}^{12}$. Hal itu merupakan imbas dari kuatnya perasaan taqlid yang ditanamkan ulama madzhab pada saat itu dan mengharamkan seorang pengikut madzhab tertentu untuk mengambil pendapat madzhab lain. ${ }^{13}$.

Secara etimologi kata talfiq (التلفيق)

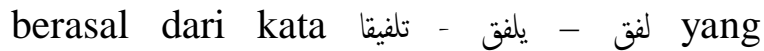
bermakna adh-dhammu (الضُّ) dan al-jam'u (الجمنح), keduanya dapat diartikan mengumpulkan atau menggabungkan. Dalam bahasa Arab menggabungkan ujung kain dengan ujung kain yang lain untuk dijahit dinamakan lafqu al-tsaubi ( لفق

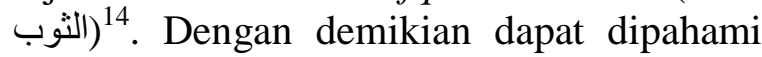
istilah talfiq dalam bermadzhab secara bahasa berarti menggabungkan pendapat suatu madzhab fiqh dengan madzhab fiqh yang lain.

Pengertian talfiq secara terminologi sendiri banyak ragam definisi yang diberikan oleh para ulama. Untuk lebih jelasnya terkait pendefinisian talfíq, di bawah ini penulis uraikan definisi talfiq dalam pandangan para ulama.

a) Wahbah al-Zuhaili ${ }^{15}$

Bertaqlid kepada madzhab-madzhab serta mengambil (menggabungkan) dua pendapat atau lebih dalam satu masalah, yang memiliki rukun-rukun

${ }^{12}$ Wahbah al-Zuhayli, Ushūl al-Fiqh ... hal. 1142

13 Abdul Aziz Dahlan, Ensiklopedi Hukum Islam, Jakarta: Ichtiar Baru van Hoeve, 1996, hal. 1786

${ }^{14}$ Fairuz Abadi, Al-Qamus al-Muhith, Juz I, Beirut: Dar al-Kutub al-'Ilmiyyah, Tt, hal. 1190-1191

${ }^{15}$ Wahbah al-Zuhaily, Ushūl al-Fiqhal...hal. 1142 dan cabang-cabang, sehingga memunculkan suatu percampuran 'amaliyah yang tidak pernah dinyatakan oleh seorang pun dari para imam mujtahid.

b) Muhammad Amin al-Kurdi al-Irbili ${ }^{16}$

Talfiq adalah mengumpulkan dua pendapat atau lebih dalam satu rangkaian hukum (qadliyah) ${ }^{17}$ yang menimbulkan suatu tata cara 'amaliyah yang keberadaannya tidak diakui oleh masing-masing pemilik madzhab yang bersangkutan.

c) Ibrahim Hosen ${ }^{18}$

Talfiq adalah beramal dalam suatu masalah menurut hukum yang merupakan gabungan dari dua madzhab atau lebih.

d) Amir Syarifudin ${ }^{19}$

Talfiq adalah mengamalkan atau beramal dalam urusan agama dengan berpedoman kepada petunjuk beberapa madzhab.

Dari beberapa definisi talfiq yang diberikan oleh para ulama di atas, dapat disimpulkan bahwa talfíq merupakan penggabungan pendapat-pendapat berbagai madzhab fiqih dalam suatu permasalahan amaliyah yang keberadaannya tidak mendapatkan legitimasi atau pengakuan dari madzhab-madzhab terkait.

\footnotetext{
${ }^{16}$ Muhammad Amin al-Kurdi al-Irbili, Tanwir al-Qulub fi Mu'amalati 'Allam al-Ghuyub, Beirut: Dar al-Fikr, 1994, hal. 356

${ }^{17}$ Qadliyah adalah sesuatu yang terdiri dari syarat, rukun, dan mubthilat (hal-hal yang membatalkan). Talfìq dalam satu qadliyah misalkan talfĩq dalam masalah wudhu atau shalat. Lihat, Majelis Musyawarah Pondok Pesantren, 112 Masalah Agama, Kediri: MMPP, 1993, hal. 69

18 Ibrahim Hosen, Memecahkan Permasalahan...hal. 35

${ }_{19}$ Amir Syarifudin, Ushul Fiqh, Jilid II, Jakarta: PT. Logos Wacana Ilmu, 1999, hal. 427
} 


\section{Kontroversi Hukum Talfīq}

Keberadaan talfiq menjadi perdebatan dikalangan ulama ushül maupun ulama fiqh, perbedaan itu muncul terkait boleh tidaknya melakukan talfiq antar madzhab. Berdasarkan hasil penelitian Ibrahim Hosen, beliau berkesimpulan bahwa perbedaan pendapat dikalangan ulama dalam masalah talfiq bersumber dari masalah boleh dan tidaknya seseorang berpindah dari satu madzhab ke madzhab lain. $^{20}$ Terkait pandangan ulama tentang boleh tidaknya talfiq, di bawah ini penulis klasifikasikan ke dalam dua golongan, yaitu pendapat yang melarang, dan pendapat yang membolehkan.

\section{a) Pendapat yang Melarang}

Pada umumnya ulama yang melarang talfiq antar madzhab dilakukan secara tegas dan mutlak. Dalam arti, talfiq tidak boleh dilakukan dalam situasi dan kondisi apapun. Salah satu pelopor ulama yang melarang talfiq adalah Imam Qaffal ${ }^{21}$, dan diikuti ulama Asy-Syinqithi, AlMu'lama yang lain, seperti: Abdul Ghani An-Nabulsi, As-Saffarini, Al-A'lawi, AlMuthi'i, dan Syeikh Muhammad Amin AsySyinqithi. $^{22}$

Adapun argumentasi yang dijadikan pegangan oleh para ulama yang melarang talfiq adalah sebagai berikut: ${ }^{23}$.

Pertama, mencegah kehancuran. Pelarangan talfiq merupakan upaya untuk mencegah kerusakan di dalam tubuh Syari'at Islam dan kehancuran berbagai madzhab fiqih yang ada dan telah mapan.

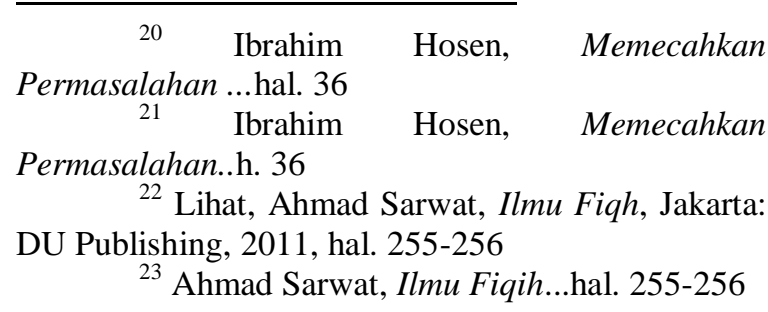

Sebab talfiq tidak lain pada hakikatnya adalah semacam kompilasi pendapat berbagai madzhab fiqih yang sudah mapan, apabila pendapat-pendapat madzhab yang merupakan hasil ijtihad para ulama mujtahid itu dikompilasikan satu sama lain, maka dengan sendirinya semua madzhab yang ada akan menjadi hilang.

Kedua, kaidah kebenaran hanya satu. Hakikat kebenaran disisi Allah, Swt., hanya satu dan itu merupakan prinsip yang dipegang teguh oleh umat Islam. Pelegitimasian talfiq merupakan bentuk pertentangan terhadap prinsip tersebut. Karena prinsip talfiq adalah memandang bahwa pendapat semua mujtahid adalah benar, padahal dalam realitasnya para mujtahid berbeda pendapat satu sama lain.

Ketiga, tidak ada nash yang membolehkan. Ketiadaan nash atau dalil yang melegitimasi kebenaran untuk melakukan talfiq antar madzhab, baik dalam al-Qur'an maupun hadits Nabi, Saw., sendiri. Dan tidak adanya contoh dari para ulama salaf sebelumnya dalam melakukan talfiq antar madzhab. Apabila ditemukan ada sebagian ulama salaf yang sekilas seperti melakukan talfiq, namun sebenarnya itu hanya anggapan generasi setelahnya yang menganggapnya sebagai talfiq, akan tetapi pada hakikatnya bukan talfiq .

Dengan argumentasi-argumentasi diatas, bagi kelompok ini, pelarangan talfíq bersifat mutlak dan mengikat tanpa alasan apapun dalam segala kondisi maupun situasi, melakukan talfiq adalah hal terlarang bagi pengikut madzhab maupun mujtahid sendiri.

b) Pendapat yang Membolehkan

Mayoritas ulama dari berbagai madzhab fiqih maupun ushul fiqh berpendapat bahwa talfiq boleh dilakukan dalam mengamalkan suatu pendapat. Salah satu pelopor yang berpendapat tentang 
kebolehan melakukan talfíq adalah al-Kamal bin Hammam dari Madzhab Hanafi ${ }^{24}$. Kemudian diikuti ulama-ulama lain dari berbagai madzhab, seperti: Imam al-Qarafi (w. 684 H/1285 M) dan Ibnu Urfah alWargami at-Tunisi atau Ibnu Urfah alMaliki keduanya dari madzhab Maliki, dan sebagian ulama madzhab Syafi' 'i ${ }^{25}$.

Argumentasi para ulama yang berpendapat tentang kebolehan melakukan talfiq adalah firman Allah, Swt.:

$$
\begin{aligned}
& \text { وَمَا جَعَلَ عَلَيْكُ فِي الَّدينِ مِنْ حَرَجِ } \\
& \text { “..dan Dia (Allah) sekali-kali }
\end{aligned}
$$

tidak menjadikan untuk kamu dalam agama suatu kesulitan..." (QS. Al-Hajj: 78)

Juga hadits Nabi, Saw.:

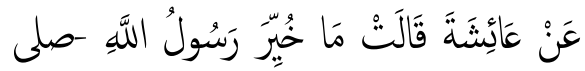

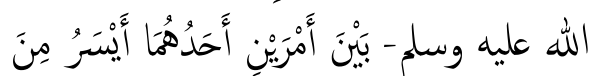

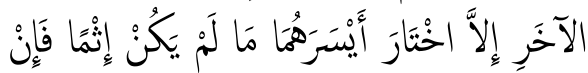

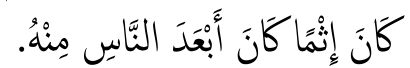

"Tidaklah Rasulullah saw. diberi pilihan antara dua hal, kecuali beliau memilih yang paling mudah di antara keduanya, jika itu tidak perkara dosa. Jika itu perkara dosa, maka beliau paling menjahui dari perkara itu dibandingkan manusia siapapun.” (HR. BukhariMuslim).

Ulama fiqih (fuqaha) sendiri berpendapat bahwa talfiq dapat dilakukan pada hukum-hukum furu' (cabang) yang ditetapkan berdasarkan dalil dhanni (kebenarannya tidak pasti). Sedangkan

\footnotetext{
${ }^{24}$ Lihat, Ibrahim Hosen, Memecahkan Permasalahan...h. 36

${ }_{25}$ Abdul Aziz Dahlan, Ensiklopedi Hukum ... hal. 1786
}

dalam permasalahan dasar syari'at, seperti akidah, akhlaq, dan permasalahan agama yang bersifat qath' $i$, tidak termasuk dalam ruang lingkup talfiq. Sebab dalam semua permasalahan tersebut, tidak berlaku taqlid, bahkan juga bukan termasuk ruang lingkup ijtihad yang memunculkan kontroversi pendapat. $^{26}$

Statemen para ulama yang memperbolehkan pelaksanaan talfiq sendiri tidaklah secara mutlak, para ulama memberikan ketentuan-ketentuan dibolehkannya memilih pendapat yang termudah dalam mengamalkan suatu ajaran agama. Ketentuan-ketentuan tersebut adalah sebagai berikut: ${ }^{27}$

1) Mengambil cara yang termudah tersebut harus disebabkan karena adanya udzur. Dalam hal ini Imam Ghazali mengatakan bahwa, talfiq tidak boleh didasarkan pada keinginan mengambil yang termudah dengan dorongan hawa nafsu, dan hanya boleh apabila adanya udzur atau situasi yang menghendakinya.

2) Talfiq tidak boleh dilakukan apabila akan berdampak kepada pembatalan terhadap keputusan hakim, karena apabila hakim telah menentukan suatu pilihan hukum dari beberapa pendapat tentang suatu masalah, maka hukum itu wajib ditaati.

3) Talfiq yang akan mengakibatkan pencabutan suatu perbuatan yang telah dilakukan dengan bertaqlid pada madzhab lain. Atau talfiq yang akan mengakibatkan pelanggaran terhadap hasil penetapan ijma'. Misalnya, seorang suami berkata kepada istrinya انت طالق البتة (kamu jelas tertalak), dan suami tersebut

\footnotetext{
${ }^{26}$ Wahbah al-Zuhaily, Ushūl Fiqh...hal. 1151

27 Lihat, Wahbah al-Zuhaily, Ushūl Fiqh...hal. 1148. Juga lihat, Abdul Aziz Dahlan, Ensiklopedi Hukum ... hal. 1786
} 
berkeyakinan bahwa talaknya jatuh tiga kali karena ia mengikuti pendapat ulama yang mengatakan itu, dan ia juga menganggap istrinya haram atau tidak boleh dirujuk. Namun, setelah kejadian itu, ia berubah keyakinan dan menganggap bahwa talaknya jatuh hanya satu, sehingga ia boleh merujuk istrinya, hal tersebut karena ia mengikuti pendapat ulama lain yang mengatakan bahwa talaknya hanya jatuh satu kali. Dalam kasus ini, maka ia wajib tetap berpegang kepada pendapat pertama, artinya status istrinya tersebut tidak boleh dirujuk kembali dengan keyakinannya yang baru.

\section{Ibrahim Hosen dan Pemikirannya Biografi Singkat Ibrahim Hosen}

Ibrahim Hosen merupakan anak kedelapan dari dua belas bersaudara dari pasangan KH. Hosen dan Siti Zawiyah. Ayahnya adalah seorang ulama sekaligus saudagar besar keturunan Bugis, sedangkan Ibunya merupakan keturunan bangsawan dari keluarga ningrat Kerajaan Selebar Bengkulu. Ibrahim Hosen dilahirkan pada tanggal 01 Januari 1917 di sebuah dusun perbatasan kota Tanjung Agung Bengkulu. ${ }^{28}$

Pendidikan formal Ibrahim Hosen dimulai pada Madrasah al-Sagaf, tingkat Ibtidaiyah di Singapura. Setelah lulus dari Madrasah al-Sagaf, kemudian beliau melanjutkan pendidikannya di Mu'awanatul Khaer Arabische School (MAS) di Tanjung Karang, sekolah yang didirikan oleh orang tuanya. Pada tahun 1932, beliau melanjutkan sekolahnya di Teluk Betung. Di luar waktu sekolah, Ibrahim Hosen menggunakan

\footnotetext{
${ }^{28}$ Panitia Penyusun Biografi, Prof. $K H$.. Ibrahim Hosen dan Pembaharuan Hukum Islam di Indonesia, Jakarta: Putra Harapan, 1990, hal. 24.
}

kesempatan untuk belajar agama dan bahasa Arab kepada Kyai Nawawi, seorang ulama besar yang pernah belajar dan menjadi guru di Makkah selama kurang lebih 12 tahun. Dan dari kyai inilah ia memperoleh kelebihan dalam penguasaan ilmu-ilmu agama, terutama bahasa Arab dan Fikih. ${ }^{29}$

Pada usia 17 tahun, Ibrahim mulai berpisah dari orang tuanya. Ia berkelana ke sejumlah pesantren. beliau mengawali berguru pada KH Abdul Latif di Cilegon, Banten. Lalu, ia pergi ke Jami'at Kheir di Jakarta untuk belajar pada ahli sastra Arab, Sayyid Ahmad As-Segaf, yang ternyata sudah pindah ke Solo. Ibrahim kembali ke Banten untuk belajar ilmu qiraat pada $\mathrm{KH}$ Tubagus Sholeh Ma'mun di Pesantren Lontar, Serang. Bekal itulah yang kelak mendorongnya mendirikan Perguruan Tinggi Ilmu Al-Qur'an (khusus laki-laki) pada tahun 1971 dan Institut Ilmu Al-Qur'an (khusus wanita,) pada tahun 1977, dimana Mahasiswanya wajib menghafal Al-Quran. Dari Serang, Ibrahim menuju Pesantren Buntet, Cirebon, belajar ilmu mantiq, fikih, dan ushul fiqih pada $\mathrm{KH}$ Abbas. Pesan Kiai Abbas pula yang membentuk cara pandang Ibrahim hingga kini, adalah "fikih itu luas. Jangan terpaku pada satu madzhab,', ujarnya. $^{30}$

Pada tahun 1940, ia memperoleh beasiswa belajar di Universitas al-Azhar Mesir. Tetapi Ibrahim Hosen tidak bisa berangkat, karena Konsul Belanda di Palembang tidak memberikan paspor. Penyebabnya, pada waktu itu Polandia diserang oleh tentara Nazi Jerman, sebagai awal pecahnya perang dunia II, sehingga situasi dunia dianggap tidak aman termasuk Mesir. Pada tahun 1955, niat Ibrahim Hosen untuk belajar di Universitas al-Azhar Mesir

\footnotetext{
${ }^{29}$ Panitia Penyusun Biografi, Prof. KH.. Ibrahim Hosen...hal. 24

${ }^{30}$ https://www.iiq.ac.id/index.php?a=artikel $\& d=$ $\underline{5 \& i d=231}$. Diakses pada tanggalm 21 Januari 2017
} 
dapat terwujud. Selama belajar di Mesir inilah, ia dapat meraih Shahadah Aliyah atau sarjana lengkap dalam bidang syariah (LML). Pada 1954, Ibrahim Hosen mengikuti Tarjih Besar Muhammadiyah di Yogyakarta. Beliau menjadi wakil Majlis Tarjih Muhammadiyah Wilayah Bengkulu. Pernah ditawari sebagai Rois Syuriah PBNU oleh KH. Bisri Sansuri dan KH. Muhammad Dachlan pada Muktamar NU ke 25 di Surabaya. $^{31}$ Pada tahun 1966, diangkat menjadi Kepala Biro Humas/LN Departeman Agama. Pada tanggal 1 April 1971, Ibrahim Hosen ditunjuk untuk menjadi Rektor PTIQ (Perguruan Tinggi Ilmu al-Qur'an) Jakarta, dan sebelumnya juga menjabat Rektor IAIN Raden Patah Palembang tahun 1964. Memasuki tahun 1976, terjadi kemelut di tubuh yayasan PTIQ, sehingga ia meninggalkan PTIQ. Selanjutnya, ia mendirikan IIQ Jakarta yang diresmikan pada tanggal 1 April 1977, yang dikhususkan untuk perempuan. PTIQ merupakan perguruan tinggi pertama di dunia yang secara khusus menghafal dan mempelajari al-Qur'an, di mana dua tahun kemudian Universitas Islam Madinah membuka fakultas khusus ilmu al-Qur'an. ${ }^{32}$

Pada tahun 1975-1980, Ibrahim Hosen duduk sebagai anggota komisi MUI. Kemudian pada masa Kepengurusan MUI periode 1980-1985 dan periode 1985-1990 ia terpilih sebagai Ketua dan mendapat kepercayaan mengetuai Komisi Fatwa. Di MUI inilah, Ibrahim Hosen banyak melibatkan diri dalam menyelesaikan persoalan-persoalan yang dihadapi umat. Dan dengan posisi beliau sebagai Ketua Komisi Fatwa, maka fatwa- fatwa beliau akan selalu didengar orang, walaupun tidak jarang fatwa-fatwa itu sering berseberangan dengan wacana yang sedang berkembang.

31 Panitia Penyusun Biografi, Prof. KH.. Ibrahim Hosen...hal. 18

32 Panitia Penyusun Biografi, Prof. KH.. Ibrahim Hosen... hal. 61
Ibrahim Hosen meninggal pada tanggal 7 Nopember 2001. ${ }^{33}$

\section{Talfĩq dalam pandangan Ibrahim Hosen}

Sebagaimana yang telah penulis uraikan diatas, bahwa para ulama berbeda pendapat terkait boleh tidaknya melakukan talfiq , disatu sisi terdapat kelompok ulama yang melarang, disisi yang lain terdapat kelompok ulama yang memperbolehkan. Perbedaan tersebut muncul, menurut Ibrahim Hosen, bersumber dari masalah tentang boleh tidaknya berpindah madzhab. Terkait kontroversi ulama dalam masalah pengamalan talfiq, Ibrahim Hosen sendiri mengklasifikasikannya kedalam tiga kelompok. $^{34}$

Pertama, kelompok yang dipelopori Imam Qaffal. Mereka berpendirian bahwa manakala seseorang telah memilih satu madzhab, ia harus berpegang pada madzhab yang telah dipilihnya, ia tidak dibenarkan pindah, baik secara keseluruhan maupun sebagian ke madzhab lain. Begitu pula dengan seorang mujtahid, manakala ia sudah memilih salah satu dalil, maka ia harus berpegang pada dalil tersebut. Hal itu disebabkan, dalil yang dipilihnya adalah dalil yang dipandangnya kuat (räjih). Dalil-dalil lain yang tidak dipilihnya berarti lemah (marjūh), sehingga secara rasional hal itu mengharuskan ia mengamalkan dalil yang dipandangnya kuat tersebut. Demikian juga bila seorang muqallid (orang yang taqlid) telah memilih pendapat salah satu madzhab, berarti ia telah memilih apa yang secara ijmāli dipandangnya kuat. Secara logis, ia tentu harus tetap mempertahankan pilihannya itu.

33 Hasan Basri, Majlis Ulama Indonesia, Fatwa dan Prof. KH. Ibrahim Hosen, dalam Prof. KH. Ibrahim Hosen dan Pembaharuan Hukum Islam di Indonesia,Jakarta: CV. Tiga Sembilan, 1990, hal. 239.

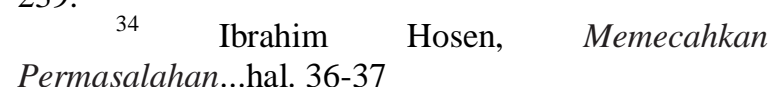


Pelarangan talfiq di atas, mendasarkan argumentasinya kepada pendapat yang mewajibkan untuk konsisten dalam bermadzhab. Sebagaimana yang telah penulis uraikan sebelumnya, berkaitan dengan perbedaan ulama tentang wajib tidaknya konsisten terhadap madzhab yang dianut, disatu sisi terdapat pendapat yang mewajibkan untuk konsisten, dan disisi yang lain tidak mewajibkan. Bagi pendapat yang mewajibkan konsisten terhadap madzhab yang dianut, maka menjadi suatu kewajiban bagi penganut madzhab fiqh untuk merujuk semua 'amaliyah-nya terhadap madzhab tersebut. Sehingga hal ini berimplikasi kepada pelarangan dalam melakukan talfiq baik sebagian maupun secara keseluruhan dan menganggap batal segala bentuk 'amaliyah yang dilakukan dengan talfiq.

Menurut Wahbah Zuhayli, bahwa pandangan ulama yang melarang talfiq dan menghukumi batal segala amaliyah yang dilakukan dengan talfiq, ditentang keras oleh beberapa ulama. Penentangan tersebut karena dilihat dari dua aspek, yakni aspek peniadaan dan pembalikan hukum.

Dari aspek peniadaan, bahwa istilah talfiq merupakan suatu istilah baru yang dimunculkan oleh ulama muta'akhirin, disaat umat Islam lebih cenderung untuk melakukan taqlid. Oleh sebab itu, istilah talfiq tidak dikenal pada masa-masa sebelumnya, baik itu pada masa Nabi, Saw., masa shahabat Nabi, Saw., maupun masa imam madzhab.

Masa Nabi Muhammad, Saw., merupakan masa proses turunnya wahyu, segala permasalahan yang muncul dikalangan umat Islam pada saat itu dapat ditanyakan langsung kepada beliau, Saw., yang memiliki otoritas tasyri'. Terlebih lagi pada masa itu, ijtihad dapat dikatakan jarang terjadi, kalaupun ada shahabat yang melakukan ijtihad, biasanya mengkonfirmasikan kembali kepada Nabi,
Saw., perihal ijtihadnya, dan adakalanya beliau membenarkan, dan adakalanya beliau meluruskannya. Sehingga hal ini dapat meminimalisir terjadinya perbedaan pendapat dikalangan shahabat.

Begitu pula pada masa Shahabat pasca wafatnya Nabi, Saw., mereka tidak mempermasalahkan 'amaliyah yang dilakukan atas dasar talfiq. Karena mereka terbiasa bertanya kepada siapapun, tanpa membatasi satu orang atau lebih. Begitu pula fatwa-fatwa mereka, tidak ada keharusan untuk mengikutinya, serta tidak melarang mereka untuk mengikuti shahabat Nabi, Saw., lainnya. Tidak jauh berbeda dengan masa Shahabat, pada masa Imam Madzhab pun tidak pernah melarang talfiq .

Realitas diatas menjadi sisi melemahkan pendapat ulama yang menolak talfiq. Karena apabila talfiq dilarang, maka hal itu bertolak belakang dengan realitas yang terjadi pada masa shahabat Nabi, Saw., dan masa Imam Madzhab fiqh, yang cenderung memperbolehkan umat Islam untuk bertanya kepada orang-orang yang dianggap kredibel dalam memahami hukum Islam (tafaqqahu fi addinn).

Dalam suatu riwayat dikatakan bahwa Imam Ahmad ibn Hanbal pernah berkata kepada murid-muridnya:

"Wahai murid-muridku,
janganlah kalian memaksakan orang-
orang untuk ikut kepada madzhabmu,
biarkan mereka mengikuti pendapat-
pendapat yang lain, agar tidak merasa
sempit dalam hidupnya."

Di lain waktu, pada saat Imam Ahmad ibn Hanbal ditanya oleh seorang laki-laki perihal permasalahan talak, beliau menjawab: "talaknya sah". Lelaki tersebut bertanya kembali: "Apabila ada ulama yang mengatakan talaknya tidak terjadi?". Imam Ahmad kembali menjawab: "Silahkan untuk 
diamalkan, karena orang-orang terdahulu tidak selalu konsisten dalam bermadzhab". 35

Sedangkan dari aspek pembalikan hukum, ketetapan para ulama tentang ketidakwajiban untuk konsisten dalam bermadzhab bagi orang awam, akan memberikan kebebasan untuk melakukan talfiq. Apabila tidak demikian, maka status 'amaliyah yang dilakukan oleh orang awam pada umumnya banyak yang dinyatakan tidak sah. Hal ini terjadi karena banyak kita jumpai praktek ibadah yang dilakukan orang awam tidak sesuai dengan madzhab tertentu. Demikian pula dengan mensyaratkan kondisi darurat untuk diperbolehkan melakukan talfiq, merupakan suatu hal sulit bagi orang awam, baik dalam permasalahan ibadah atau mu'amalah. Fakta demikian bertentangan dengan prinsip syari'at Islam itu sendiri, yang memberikan kemudahan dan juga kemaslahatan.

Kedua, kelompok yang dipelopori oleh al-Kamal ibn al-Hammam. Mereka berpendirian bahwa orang yang telah memilih salah satu madzhab, Islam tidak melarangnya untuk berpindah ke madzhab lain, walaupun maksud berpindahnya itu adalah untuk mencari keringanan. Ia dibenarkan mengambil dari tiap-tiap madzhab pendapat yang dipandangnya mudah dan ringan. Rasulullah, Saw. sendiri, apabila disuruh memilih satu di antara dua hal, beliau akan memilih yang paling mudah dan ringan. Hal ini sejalan dengan hadits yang diriwayatkan 'Aisyah: "Sesungguhnya Rasulullah, Saw., senang mempermudah umatnya" (HR.Bukhāri). Dalam sabdanya yang lain, Nabi, Saw., bersabda:

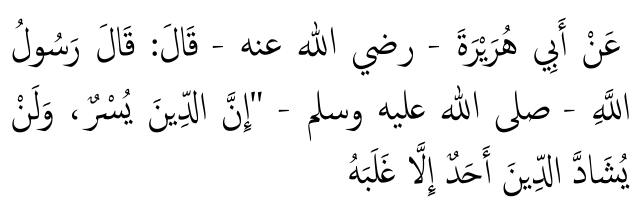

${ }^{35}$ Muhammad bin Ali bin Muhammad alSyaukani, Irsyād al-Fuhūl...hal. 272
"Dari Abi Hurairah, Nabi saw bersabda: "Sesungguhnya agama itu mudah dan tiada seseorang yang mempersulit agama melainkan pasti ia akan dikalahkan" (HR. Bukhari) ${ }^{36}$

Pendapat Al-Kamal bin Hamam diatas, diamini pula oleh muridnya, Ibn Amir al-Haj, berkata:

"Seorang muqallid boleh mengikuti madzhab siapa saja. Dan, status hukum tentang orang awam yang mengikuti pendapat yang ringan, belum pernah aku temukan celah hukum yang melarangnya, baik dalil aqli maupun naqli, bahkan tidak pernah aku ketahui dalil-dalil yang mencelanya. Rasulullah, Saw., sendiri lebih menyukai sesuatu yang mudah bagi umatnya". 37

Pendapat ini banyak didukung oleh para ulama, seperti Ibn Abidin, Syaikh athThursi, Ibn Najm, Abu Su'ud, dan Ibn 'Arafah.

Ketiga, yang dipelopori oleh Imam al-Qarafi. Mereka berargumentasi bahwa seseorang yang telah memilih madzhab, dapat berpindah ke madzhab lain, walaupun dengan motivasi mencari kemudahan, dengan syarat bukan pada kasus hukum (dalam satuan qadliyah) yang sepakat dibatalkan oleh imam madzhabnya yang semula dan imam madzhabnya yang baru. Misalnya, seseorang yang bertaklid kepada madzhab Syafi'i hendak bertaklid kepada madzhab Maliki tentang tidak batalnya wudhu karena menyentuh wanita bukan mahram tanpa syahwat, maka dalam berwudhu hendaknya ia menggosok-gosok anggota wudhunya dan harus menyapu seluruh kepalanya. Menurut madzhab Maliki, menggosok-gosok sewaktu

36 Muhammad ibn Ismail Abu Abdillāh alBukhari, Shahīh al-Bukhāri, Juz I, Beirut: Dār ibn Katsīr al-Yamāmah, 1987, hal. 23

37 Al-Kamāl ibn al-Humam, al-Tahrīr, Beirut: Dar al-Fikr , tt., hal. 79 
membasuh anggota wudhu termasuk fardhu wudhu dan seluruh kepala wajib disapu. Apabila wudhunya tidak dilakukan dengan cara semacam itu, maka wudhunya dianggap batal, begitu juga dengan salat yang dilakukannya, baik menurut Syafìi (karena ia telah menyentuh wanita bukan mahram), maupun menurut Maliki (karena dalam berwudhu ia tidak menggosok dan tidak menyapu seluruh kepala). Perbuatan semacam inilah yang terkenal dengan istilah talfiq dan menurut mereka tidak bisa dibenarkan.

Menurut wahbah al-Zuhaily, bahwa pada hakikatnya batasan yang dikemukakan oleh Imam al-Qarafi di atas, tidak memiliki landasan dalil baik dari nash maupun ijma'. Kamal bin Hamam dalam kitab al-Tahrirnya menegaskan bahwa batasan yang dikemukakan oleh al-Qarafi adalah batasan yang muncul belakangan, dan belum pernah ada sebelumnya. ${ }^{38}$

Dari pengklasifikasian pendapat ulama terkait talfiq yang dilakukan Ibrahim Hosen di atas, berdasarkan hasil penelaahan dan penelitiannya, beliau lebih cenderung kepada pendapat yang dikemukakan oleh Kamal bin Hamam. Kecenderungan beliau tersebut karena melihat sisi dalil dan kemashlahatan yang dikemukakan oleh Kamal bin Hamam adalah yang terkuat dibandingkan dengan argumentasi ulama lain terkait kebolehan talfiq, dengan alasan berikut: ${ }^{39}$

1. Tidak ada nash al-Qur'an maupun Sunnah yang mewajibkan seseorang harus terikat dengan salah satu madzhab saja. Demikian juga, tidak ada nash alQur'an maupun Sunnah yang secara jelas melarang seseorang untuk berpindah madzhab. Yang ada adalah nash tentang kewajiban bagi orang

\footnotetext{
${ }^{38}$ Wahbah al-Zuhayli, Ushül al-Fiqh...hal. 1155

39 Ibrahim Hosen, Memecahkan Permasalahan... h. 37-39
}

awam yang tidak mengerti untuk bertanya kepada ahl al-dzikr.

2. Pada hakikatnya, talfiq berlaku hanya pada masalah fiqhiyah (hasil ijtihad para ulama mujtahid). Dalam masalah ini berlaku kaidah "al-Ijtihād lā yunqadhu bi al-Ijtihād" (ijtihad tidak dapat digugurkan oleh ijtihad yang lain), dan penerapan talfiq harus mengikuti kondisi dan situasi sesuai dengan kemaslahatan.

Mewajibkan seseorang untuk terikat kepada salah satu madzhab akan mempersulit umat, hal ini tidak sejalan dengan prinsip umum syariat hukum Islam yaitu kemudahan dan kemaslahatan, di samping tidak sejalan dengan penegasan Nabi saw: "Perbedaan pendapat di kalangan umatku (ulama) akan membawa rahmat" (HR. al-Baihaqi).

3. Pendapat yang tidak membenarkan seseorang untuk berpindah madzhab, muncul dari kalangan ulama khalāf (muta'akkhir) setelah mereka dihinggapi penyakit fanatik madzhab. Membiarkan hal ini bukan saja menyebabkan umat Islam terkotakkotak dan pecah, tetapi juga menyebabkan fiqh menjadi beku dan kaku.

4. Membenarkan talfiq bukan saja dapat membawa pada kelapangan, tapi juga akan menjadikan fiqh selalu dinamis dan dapat menjawab tantangan zaman. Pengkajian komparatif atas fiqh akan tumbuh subur dan dengan demikian figh akan selalu berkembang dan hidup

5. Membenarkan talfiq tapi dengan syarat bukan pada satu qadhiyah, menurutnya bertentangan dengan realitas. Imam Syafi'i tidak pernah mengaitkan ayat tentang menyapu kepala (famsahu biru'ūsikum) dengan ayat tentang menyentuh wanita/bersetubuh (aw lāmastum al-nisā'). Demikian juga 
Imam Malik tidak pernah mengaitkan ayat tentang menyapu kepala dengan hadits tentang anjing menjilat bejana sebab terdapat nash tentang hukum menyapu kepala, bersentuhan dengan wanita bukan mahram, dan jilatan anjing.

6. Kenyataan yang terjadi di kalangan sahabat menunjukkan bahwa orang boleh meminta penjelasan hukum (istiftā') kepada sahabat yunior (mafdhûl), walaupun ada sahabat lain yang lebih senior (fadhil). Hal ini menurutnya sudah ijmā sahabat. Oleh sebab itu, tidak mengherankan kalau masing-masing Imam Mujtahid membenarkan orang awam mengamalkan pendapat yang lemah (marjûh). Mengenai orang awam, mereka tidak mempunyai madzhab (al'àm lā madzhaba lahu), hal ini menunjukkan bahwa orang awam tidak terikat dengan salah satu madzhab. Inilah menurutnya hakikat .

Dari beberapa argumentasi yang dikemukakan oleh Ibrahim Hosen di atas, terkait kecenderungannya kepada kebolehan talfiq, sebagaimana halnya Kamal bin Hamam, dapat digaris bawahi bahwa kebolehan talfiq merupakan sejalan dengan prinsip yang memberi kemudahan kepada umatnya dalam menjalankan segala apa yang diperintahkan Syari'at. Dengan demikian pelarangan talfiq bertolak belakang dengan prinsip yang dibawa oleh syari'at Islam itu sendiri. Dan pelarangan tailfìq sendiri tidak memiliki landasan dalil, baik dari al-Qur'an maupun Hadits Nabi, Saw., maupun tradisi yang dipegang oleh para shahabat maupun para Imam Madzhab yang memberi kebebasan kepada umat Islam untuk bertanya dan mengambil pendapat ulama yang disukai. Sehingga dengan realitas tersebut, kebolehan talfiq merupakan salah satu bentuk pengejawantahan prinsip kemudahan yang dibawa oleh Islam.
Akan tetapi, kebolehan talfiq yang dipegang oleh Ibrahim Hosen tidaklah bersifat mutlak, hal ini sebagaimana yang beliau katakan di atas, bahwa penerapan talfiq harus mengikuti kondisi dan situasi sesuai dengan kemaslahatan. Dalam artian, pengamalan talfĩq sendiri tergantung dari bentuk motivasi pengamalannya. Pengamalan talfiq yang memiliki motif hanya mencari yang mudah-mudah (tatabu al-rukhshah) dalam pengamalan syari'at, hal itu tidak diperbolehkan. Namun, apabila karena situasi dan kondisi yang tidak memungkinkan apabila berpegang pada pendapat madzhab yang selama ini dipegang dan terdapat pendapat madzhab lain yang lebih memudahkan, maka dalam kondisi demikian, pengamalan talfiq diperbolehkan. Hal ini, sebagaimana statemen para ulama yang memperbolehkan pelaksanaan talfiq tidaklah secara mutlak, akan tetapi pada batasan-batasan tertentu, sebagaimana yang telah penulis uraikan sebelumnya.

Selanjutnya, menurut Ibrahim Hosen bahwa kebolehan talfīq dalam masalah ibadah (yaitu masalah kemasyarakatan) yang dipegang oleh Kamal bin Hamam dan Imam al-Qarafi, ini berlaku hanya bagi Ulil amri (pemerintah) atau qadli (hakim) demi kemaslahatan umum, bukan demi mencari keringanan.

Dari pendapat Ibrahim Hosen diatas dapat dikatakan bahwa, apabila talfiq dilakukan oleh suatu negara dalam pembentukan suatu peraturan yang akan dijalankan umat Islam, atau oleh Hakim guna menyelesaikan persengketaan yang sedang diadilinya, maka tidak ada alasan untuk menolaknya. Karena suatu negara atau hakim dalam melakukan talfĩq tersebut untuk umatnya berdasarkan kemashlahatan umum. Hal ini sebagaimana yang dikatakan dalam kaidah fiqh, bahwa:

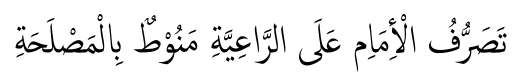




"Kebijakan pemimpin kepada
rakyatnya harus sesuai dengan
kemaslahatan atau kesejahteraan
rakyatnya"

Kaidah ini menegaskan bahwa seorang pemimpin harus mengedepankan aspek kemaslahatan rakyat bukan mengikuti keinginan hawa nafsunya, atau keinginginan keluarganya atau kelompoknya. Kaidah ini juga diperkuat dengan QS. An-Nisa ayat 58 yang berbunyi;

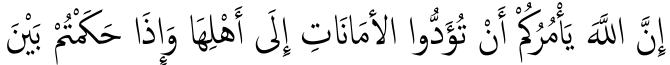

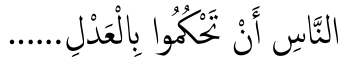

$$
\begin{aligned}
& \text { "Sesungguhnya } \\
& \text { Allah }
\end{aligned}
$$

menyuruh kamu menyampaikan amanat kepada yang berhak menerimanya, dan (menyuruh kamu) apabila menetapkan hukum di antara manusia supaya kamu menetapkan dengan adil."

Berbeda halnya pengamalan talfiq yang dilakukan oleh ulil amri (pemerintah) atau qadli (hakim), bagi orang awam menurut Ibrahim Hosen terkait dalam masalah ibadah, sebagai bentuk kehatihatian (ihtiyath) serta saddan li dzari'at ${ }^{40}$, sebaiknya orang awam mengikuti salah satu madzhab yang mudawwan dan mu'tabar (kebenaran sanad dan keilmiahannya dapat dipertanggung jawabkan). Dan dalam halhal tertentu, orang awam dapat mengikuti madzhab lain yang dipandang kuat (räjih)

40 Secara etimologi dzari'ah adalah perantara, sarana, atau jalan menuju sesuatu secara umum. Sedangkan dalam terminologi syari'at, dari'ah adalah sarana atau perantara menuju sesuatu yang dilarang oleh syari'ah. Pengertian inilah yang paling umum digunakan. Dan, karena secara literal, sadd bermakna menutup, mengunci, mencegah, menyumbat (preventif) karena adanya larangan untuk melakukannya, maka dengan demikian saddan li dzari'at adalah tindakan menutup segala jalan yang menjadi perantara pelanggaran larangan syari'at. Lihat, Muhammad Musthafa Syalbi, Ushul al-Fiqh al-Islami, beirut: Dar al-Nahdlah al-'Arabiyyah, 1986, h. 300. dan lebih membawa kepada kemaslahatan. Dengan jalan ini, ibadah akan dapat dilakukan dengan penuh kehati-katian, dan pintu kelapangan pun tetap terbuka, sehingga kita tidak akan kesulitan (masyaqqah) dalam beribadah. ${ }^{41}$

Pendapat Ibrahim Hosen terkait kecenderungannya kepada orang awam untuk mengikuti salah satu madzhab dalam masalah ibadah, terlihat masih bersifat umum. Karena ibadah dalam Islam sendiri memiliki aspek yang begitu luas, dengan realitas demikian menurut Wahbal Zuhaily bahwa ibadah yang berlandaskan atas dasar kemudahan dan toleran, dan berubah-ubah kadarnya mengikuti kondisi seseorang, seperti ibadah mahdlah (ritual), maka dalam hal ini talfiq diperbolehkan bila ada kebutuhan. Karena yang menjadi muara disyari'atkannya ibadah mahdlah adalah ketaatan kepada Allah, Swt., dan penghambaan kepada-Nya, bukan mempersulit. Sedangkan dalam permasalahan ibadah maliyah, haruslah diperketat, agar tidak menyia-nyiakan hak fakir miskin. Karenanya dalam praktik zakat, sebaiknya tidak mengambil pendapat yang lemah atau melakukan talfīq yang akan berakibat penelantaran hak-hak fakir miskin. Dan bagi para mufti, dalam memberikan fatwa seputar permasalahan ibadah maliyah ini haruslah menerapkan prinsip kehatihatian, dengan memperhatikan kondisi peminta fatwa. $^{42}$

Dengan demikian, dapat disimpulkan bahwa dalam aspek ibadah māliyah, prinsip kehati-hatian harus diterapkan, karenanya sebagaimana yang dikatakan Ibrahim Hosen di atas, bahwa bagi orang awam lebih baik berpegang kepada salah satu madzhab yang selama ini dipegangi, agar hak yang dimiliki oleh fakir

\footnotetext{
${ }^{41}$ Ibrahim Hosen, h. 39

42 Wahbah al-Zuhaily, Ushūl al-Fiqh...h. 1151
} 
miskin tidak terabaikan. Sehingga dengan sikap demikian, kemaslahatan yang menjadi tujuan syari'at dapat terealisasikan. talfiq Akan tetapi dalam aspek ibadah mahdlah, pengamalan talfíq terbuka lebar dengan catatan dalam kondisi yang memang ada kebutuhan untuk pelaksanaannya.

\section{DAFTAR PUSTAKA}

Abadi, Fairuz. Al-Qamus al-Muhith. Beirut: Dar al-Kutub al-'Ilmiyyah. Tt

Al-Bukhari, Muhammad ibn Ismail Abu Abdillāh. Shahīh al-Bukhāri. Beirut: Dar ibn Katsir al-Yamamah. 1987.

Al-Buthi, M. Said Ramadhan. Alamadzhābiah Akhthuru Bid'atin Tuhaddidu al-Syari'ah al-Islamiyah. diterjemahkan oleh Gazira Abdi Ummah. Jakarta: Pustaka AlKautsar. 2001.

Al-Humam, Al-Kamāl ibn. al-Tahrīr. Beirut: Dar al-Fikr . Tt.

Al-Irbili, Muhammad Amin Kurdi. Tanwir al-Qulub fi Mu'amalati 'Allam alGhuyub. Beirut: Dar al-Fikr. 1994.

Al-Syaukani, Muhammad bin Ali bin Muhammad. Irsyād al-Fuhūl ilā Tahqīq al-Haqq min 'Ilm al-Ushūl. Beirut: Dar al-Fikr. Tt.

Al-Zuhaily, Wahbah. Ushūl al-Fiqh alIslāmi. Juz II. Beirut: Dar al-Fikr. 1989

Azka. et.al, Darul. Lubb al-Ushul: Kajian Intisari Dua Ushul. Lirboyo: Santri Salaf Press. 2017.

Basri, Hasan. Majelis Ulama Indonesia. Fatwa dan Prof. KH. Ibrahim Hosen. dalam Prof. KH. Ibrahim Hosen dan Pembaharuan Hukum Islam di Indonesia. Jakarta: CV. Tiga Sembilan. 1990.

Biografi, Panitia Penyusun. Prof. KH.. Ibrahim Hosen dan Pembaharuan Hukum Islam di Indonesia. Jakarta: Putra Harapan. 1990.
Dahlan, Abdul Aziz. Ensiklopedi Hukum Islam. Jakarta: Ichtiar Baru van Hoeve. 1996.

Efendi, Djohan. Pembaharuan Tanpa Membongkar Tradisi: Wacana Keagamaan di Kalangan generasi Muda NU Masa Kepemimpinan Gus Dur. Jakarta: Kompas. 2010.

Hosen, Ibrahim. Memecahkan Permasalahan Hukum Baru. dalam Jalaluddin Rahmat (ed.) Ijtihad Dalam Sorotan. Bandung: Mizan. 1992.

Kebudayaan, Departemen Pendidikan dan. Kamus Besar Bahasa Indonesia. Jakarta: Balai Pustaka. 1989.

Pesantren, Majelis Musyawarah Pondok. 112 Masalah Agama. Kediri: MMPP. 1993.

Sarwat, Ahmad. Ilmu Figh. Jakarta: DU Publishing. 2011.

Syalbi, Muhammad Musthafa. Ushul alFiqh al-Islami. Beirut: Dar alNahdlah al-'Arabiyyah. 1986.

Syarifudin, Amir. Ushul Fiqh. Jakarta: PT. Logos Wacana Ilmu. 1999.

Yanggo, Huzaemah Tahido. 2011. Pengantar Perbandingan Madzhab. Jakarta: Logos Wacana Ilmu. 1997.

\section{Website:}

https://www.iiq.ac.id/index.php?a=artikel\&d $=5 \& \mathrm{id}=231$ 